\title{
KEPUASAN USER (INSTITUSI PENGGUNA) TERHADAP MUTU LULUSAN POLTEKKES KEMENKES BENGKULU
}

\author{
Hermansyah, Eliana, Dahrizal \\ Jurusan Keperawatan Poltekkes Kemenkes Bengkulu, Jl. Indragiri No.3 Bengkulu, email: \\ man2aditya@yahoo.com \\ Jurusan Kebidanan Poltekkes Kemenkes Bengkulu, Jl. Indragiri No.3 Bengkulu \\ Jurusan Keperawatan Poltekkes Kemenkes Bengkulu Jl. Indragiri No.3 Bengkulu, email: \\ dahrizal26@ymail.com
}

\begin{abstract}
Abstrack : The purpose of this study is known the picture of user satisfaction (user institution) for the quality of Poltekkes Kemenkes Bengkulu graduates. This is the kind exploratory and descritive research that are qualitative and quantitative. Unit analysis of research data is user institution where Poltekkes kemenkes Bengkulu graduates working. While the subject of study is the leadhership of the institution / head room in which graduate work and their partner work at the institute. Subjects in this study set by purposive sampling technique followed by a snow ball sampling technique. Data was collected through structured interviews and filling out the questionnaire guidelines. Interviews were conducted to the leadership of institutions and co-workers. Data from Poltekkes Kemenkes Bengkulu graduates conducted using a questionnaire. The analysis showed that more than half $(63.6 \%)$, users opinion said that the quality of graduates were good, the majority $(72.7 \%)$ chairman and co-workers are satisfied with the performance of Poltekkes Kemenkes Bengkulu graduates, and $23.4 \%$ of graduates find a job $<3$ months after graduation and $23.4 \%$ of graduates find job after waiting 3-6 months. Poltekkes Kemenkes Bengkulu should prepare the studends to have a competitive advantage began the process of selection and education to produce qualifiedgraduates.
\end{abstract}

\begin{abstract}
Abstrak : Tujuan penelitian ini adalah diketahuinya gambaran kepuasaan user (institusi pengguna) terhadap mutu lulusan Poltekkes Kemenkes Bengkulu. Jenis Penilitian ini adalah penelitian eksploratoris dan deskriptif yang bersifat kualitatif dan kuantitatif. Unit analisis data penelitian adalah institusi pengguna dimana lulusan Poltekkes Kemenkes Bengkulu bekerja. Sedangkan subjek penelitian adalah pimpinan institusi/kepala ruangan tempat lulusan bekerja, lulusan Poltekkes Kemenkes Bengkulu, dan rekan kerja lulusan pada institusi tersebut. Subjek dalam penelitian ini ditetapkan dengan tehnik purposif sampling yang dilanjutkan dengan tehnik snow ball sampling. Pengumpulan data dilakukan dengan wawancara dengan pedoman terstruktur dan pengisian kuesioner. Wawancara dilakukan kepada pimpinan institusi dan rekan kerja. Pengumpulan data pada lulusan Poltekkes Kemenkes Bengkulu dilakukan dengan menggunakan kuesioner. Data dianalisis secara kuantitatif dan kualitatif. Hasil analisis menunjukkan bahwa lebih dari separuh $(63,6 \%)$ user berpendapat mutu lulusan adalah baik, sebagian besar $(72,7 \%)$ pimpinan dan rekan kerja puas dengan kinerja lulusan Poltekkes Kemenkes Bengkulu, dan 23,4\% lulusan dengan lama masa tunggu mendapat pekerja setelah lulus adalah $<3$ bulan serta 23,4\% lulusan mendapat pekerjaan setelah menunggu 3-6 bulan. Disaran bagi Poltekkes Kemenkes Bengkulu hendaknya mempersiapkan mahasiswa agar memiliki keunggulan bersaing (competitive adventage) mulai saat proses seleksi dan pendidikan sehingga menghasilkan lulusan yang bermutu.
\end{abstract}

Kata Kunci : kepuasan user, mutu lulusan

Dewasa ini globalisasi telah menjangkau berbagai aspek kehidupan, sehingga persaingan pun semakin tajam. Dunia pendidikan sebagai salah satu bagiannya juga mengalami hal yang sama. Organisasi pendidikan yang dulu bersaing hanya pada tingkat lokal, regional atau nasional kini harus pula bersaing dengan organisasi pen- didikan dari seluruh penjuru dunia. Hanya organisasi pendidikan yang mampu menghasilkan lulusan yang berkualitas yang dapat bersaing dalam pasar global, khususnya dalam dunia kerja (Khoiri, 2009).

Sampai saat ini masih banyak terjadi kesenjangan kualifikasi lulusan perguruan tinggi dengan kebutuhan dunia kerja atau 
institusi pengguna, terutama dalam hal kemampuan solusi masalah berdasarkan konsep ilmiah dan keterampilan kelompok (teamwork) dimana perguruan tinggi masih banyak yang mementingkan teori asal lulus ujian serta hanya menekankan keterampilan individual (Gaspersz, 2008).

Agar suatu oraganisasi pendidikan dapat memiliki keunggulan dalam skala global, maka organisasi pendidikan tersebut harus mampu melakukan pengelolaan secara baik dalam rangka menghasilkan lulusan yang berkualitas tinggi dengan biaya wajar dan bersaing. Dengan kata lain, dalam persaingan global yang modern, kunci untuk meningkatkan daya saing adalah kualitas.

Kondisi seperti tersebut di atas perlu diantisipasi lebih dini oleh organisasi pendidikan, khususnya perguruan tinggi baik yang dimiliki pemerintah maupun swasta. Masyarakat akan kritis memilih perguruan tinggi yang diinginkan, dengan pertimbangan utama yang biasa digunakannya adalah setelah lulus akan mudah mendapatkan pekerjaan yang layak. Hal semacam ini menjadi acuan suatu perguruan tinggi untuk lebih meningkatkan mutu pengelolaannya agar tujuan perguruan tinggi yang telah dicanangkan dapat tercapai (Khoiri, 2009).

Peningkatan kemampuan untuk mengelola dan mengembangkan perguruan tinggi sudah sangat dirasakan perlu, termasuk untuk menggunakan prinsip-prinsip manajemen modern yang berorientasi pada mutu/kualitas. Bagi para pemilik dan pengelola Perguruan Tinggi, sistem manajemen mutu pada hakekatnya berinti pada perbaikan terus menerus untuk memperkuat dan mengembangkan mutu lulusan sehingga dapat diserap oleh kalangan instansi dan pasar tenaga kerja. Krisis ekonomi dan moneter serta pasar bebas telah menuntut untuk lebih cermat dalam menentukan wawasan kedepan yang didasarkan atas pertimbangan potensi, kendala, peluang dan ancaman yang menuntut untuk lebih efektif dan efisien dalam bertindak (Asmawi, 2005).
Sebagaimana diketahui saat ini adalah era persaingan mutu atau kualitas dari suatu produk. Produk yang bermutu akan diminati oleh konsumen, sebaliknya apabila produk itu tidak bermutu maka akan ditinggalkan oleh konsumen. Begitupun juga perguruan tinggi di era globalisasi harus berbasis pada mutu, bagaimana perguruan tinggi dalam kegiatan jasa pendidikan maupun pengembangan sumber daya manusia yang memiliki keunggulan-keunggulan. Para mahasiswa yang sedang menuntut ilmu di perguruan tinggi sesungguhnya mengharapkan hasil ganda yaitu ilmu pengetahuan, gelar, keterampilan, pengalaman, keyakinan dan perilaku luhur yang mampu bersaing dipasar global. Semuanya itu diperlukan sebagai persiapan memasuki dunia kerja dan atau persiapan membuka lapangan kerja dengan mengharapkan kehidupan yang lebih baik dan kesejahteraan lahir serta batin.

Kenyataan yang ada pada dewasa ini menunjukkan mutu lulusan perguruan tinggi itu tidak selalu dapat diterima dan mampu untuk bekerja sebagaimana yang diharapkan dunia kerja. Maraknya perguruan tinggi berpotensi merosotnya mutu lulusan, mengingat standarisasi mutu lulusan tidak menjadi tujuan; tetapi hanya dilihat dari aspek kuantitas; yakni bagaimana mendapatkan jumlah mahasiswa sebanyak-banyaknya. Begitupun dengan diberlakukannya otonomi kampus; dimana perguruan tinggi negeri (PTN) dan swasta (PTS) memiliki kesamaan di dalam pengelolaan, sehingga ada kecenderungan untuk mencari dana yang memadai; namun terkadang mengabaikan aspek mutu itu sendiri (Asmawi, 2005).

Mutu adalah totalitas dari karakteristik suatu produk yang menunjang kemampuannya untuk memuaskan kebutuhan yang dispesifikan atau ditetapkan. Mutu sering kali diartikan sebagai kepuasan pelanggan (Gaspersz, 2008) Berdasarkan pengertian tentang mutu tersebut, tampak bahwa mutu selalu berfokus kepada pelanggan (customer focused quality). Dengan demikian produk-produk didesain, di- 
produksi, serta pelayanan diberikan untuk memenuhi keinginan pelanggan. Karena mutu mengacu kepada segala sesuatu yang menentukan kepuasan pelanggan, suatu produk yang dihasilkan atau pelayanan yang diberikan baru dapat dikatakan bermutu apabila sesuai dengan keinginan pelanggan, dapat dimanfaatkan dengan baik, serta diproduksi atau dihasilkan dengan cara yang benar (Gaspersz, 2003). Demikian halnya dengan perguruan tinggi, dikatakan lulusan perguruan tinggi tersebut bermutu jika dapat memberikan kepuasan kepada institusi pengguna yaitu tempat mereka bekerja, rekan kerja dan kepada masyarakat. Lulusan perguruan tinggi dapat memberikan kepuasan kepada institusi pengguna jika kinerja yang mereka tunjukkan sesuai atau melebihi harapan tempat mereka bekerja.

Pengukuran terhadap kepuasan institusi pengguna dan rekan kerja lulusan perguruan hendaknya dilakukan sebagai bahan evaluasi terhadap mutu pendidikan tinggi yang sudah sedikit terabaikan karena mencari dana dan lebih mengejar keuntungan semata. Hasil studi terhadap kepuasan institusi pengguna juga dapat memberkan informasi tentang kesesuaian kurikulum yang dipakai dengan pasar kerja, kompetensi lulusan, posisi lulusan pada jendela pelanggan, dan memberikan gambaran faktor-faktor yang diduga berhubungan dengan kepuasan user terhadap lulusan perguruan tinggi.

Poltekkes Kemenkes Bengkulu salah satu institusi pendidikan kesehatan yang berada di bawah BPPSDM Kes. Kemenkes RI mempunyai visi menghasilkan tenaga Kesehatan Profesional yang dapat mewujudkan masyarakat mandiri dalam mencapai hidup sehat dan dapat bersaing di pasar global. Poltekkes Kemenkes Bengkulu telah menyelenggarakan pendidikan sejak tahun 2001 dengan 2 (dua) jurusan (Keperawatan, dan Kebidanan) dan tahun 2004 menyelenggarakan Jurusan Gizi. Jumlah lulusan sampai dengan tahun 2010 sebanyak 2.570 orang, dengan prediksi penyerapan dipasar kerja sekitar $75 \%$. Jumlah dosen dengan kualifikasi S2 sampai dengan tahun 2010 berjumlah 43 orang. Dosen yang sedang mengikuti tubel S2 sebanyak 20 orang dan tubel S3 sebanyak 2 orang.

Sampai dengan tahun 2010 Poltekkes Kemenkes Bengkulu belum pernah melaksanakan kegiatan evaluasi terhadap penyerapan lulusan dan kepuasan user (institusi pengguna). Data penyerapan lulusan dan evaluasi mutu lulusan selalu disajikan berdasarkan dugaan dan proyeksi semata sehingga tidak memberikan data yang valid. Belum diketahui apakah lulusan Poltekkes Kemenkes Bengkulu bermutu baik dan dapat memberikan kepuasan pada pema$\mathrm{kai} /$ user.

Tujuan penelitian ini adalah untuk mengetahui gambaran kepuasaan user (institusi pengguna) terhadap mutu lulusan Poltekkes Kemenkes Bengkulu.

\section{BAHAN DAN CARA KERJA}

Penelitian ini dilakukan dengan dua tahap yaitu penelitian eksploratoris dan ju-ga penelitian deskriptif yang bersifat kualitatif dan kuantitatif, dengan 2 tahapan ini diharapkan diperoleh informasi yang saling menunjang satu sama lain. Adapun riset deskriptif dalam penelitian ini dengan desain cross-sectional study, dimana pengukuran dilakukan dalam satu waktu tertentu.

Unit analisis data penelitian adalah institusi pengguna dimana lulusan Poltekkes bekerja. Sedangkan subjek penelitian adalah pimpinan institusi/kepala ruangan tempat lulusan bekerja, lulusan Poltekkes, dan rekan kerja lulusan pada institusi tersebut. Subjek dalam penelitian ini ditetapkan dengan tehnik purposif sampling dengan kriteria subjek penelitian berada di Propinsi Bengkulu dan sekitar Propinsi Bengkulu. Pengambilan subjek penelitian selanjutnya dengan menggunakan tehnik snow ball sampling, yakni pengumpulan data melalui wawancara mendalam dari satu responden ke responden lainnya dan seterusnya sampai peneliti tidak menemukan informasi baru lagi, jenuh, atau informasi "tidak bekualitas" lagi. 
Penelitian menggunakan data primer berupa kuesioner dan pedoman wawancara untuk rekan kerja bersisi tentang data pribadi/informasi biografi, penilaian kepuasan terhadap lulusan, tingkat kemampuan lulusan, kompetensi indivudual, dan penguasaan kompetensi umum. Pedoman wawancara untuk pimpinan institusi berisi tentang data pribadi/informasi biografi, data personalia, penilaian kepuasan terhadap lulusan, tingkat kemampuan lulusan, kompetensi individual, penguasaan kompetensi umum, dan kompetensi yang dibutuhkan institusi.

Analisis yang dilakukan pada penelitian ini adalah analisis kuantitatif dan kualitatif dengan triangulasi metode dan sumber.

\section{HASIL}

Penelitian dilaksanakan pada bulan Maret s.d Juli tahun 2011 di beberapa instansi kesehatan di Propinsi Bengkulu tempat alumni Poltekkes Kemenkes Bengkulu bekerja, antara lain di Kota Bengkulu, Kabupaten Kepahiang, Seluma, Bengkulu U- tara, Rejang Lebong, Lebong, Bengkulu Selatan, Muko-muko, dan Kabupaten Lubuk Linggau Propinsi Sumatera Selatan. Pengumpulan data dilaksanakan terhadap 154 lulusan Poltekkes Kemenkes Bengkulu, 15 orang pimpinan, 45 orang rekan kerja lulusan, dan untuk kuesioner kepuasan diisi oleh 11 rekan kerja dan pimpinan dari lulusan.

Hasil penelitian disajikan dalam analisis kualitatif dan kuantitatif secara bersamaan. Analisis kuantitatif dilakukan secara univariat.

\section{Kesesuaian Kurikulum Dan Pemanfaatan Kompetensi Lulusan Terhadap Kebutuhan User (Institusi Pengguna)}

Hasil pengumpulan data dengan menggunakan kuesioner dan wawancara terhadap kesesuaian kurikulum yang didapatkan lulusan selama mengikuti perkuliahan di Poltekkes Kemenkes Bengkulu dengan kebutuhan user dapat dilihat pada tabel berikut.

Tabel 1. Distribusi Lulusan Berdasarkan Pendapat tentang Kesesuaian Kurikulum Poltekkes Kemenkes Bengkulu Terhadap Kebutuhan Institusi Pengguna Tahun 2011

\begin{tabular}{lcc}
\hline \multicolumn{1}{c}{ Variabel } & Frekuensi (f) & Prosentase $(\boldsymbol{\%})$ \\
\hline Relevansi Ilmu Dengan Karier & & 1,3 \\
Sangat Tidak Relevan & 2 & 0,6 \\
Tidak Relevan & 1 & 46,8 \\
Relevan & 72 & 18,2 \\
Sangat Relevan & 28 & 33,1 \\
Tidak Memberikan Jawaban & 51 & 57,1 \\
Keterampilan Bermanfaat Bagi Kemajuan Karier & & 3,3 \\
Ya & 88 & 39,6 \\
Tidak & 5 & $\mathbf{1 0 0}$ \\
Tidak Memberikan Jawaban & 61 & $\mathbf{1 5 4}$ \\
Jumlah & $\mathbf{1 5 4}$ & \\
\hline
\end{tabular}

Berdasarkan tabel di atas dapat diketahui bahwa hampir separuh $(46,8 \%)$ responden menyatakan bahwa ilmu yang diperoleh di Poltekkes Kemenkes Bengkulu relevan dengan peningkatan karier, dan lebih dari separuh $(57,1 \%)$ responden menyatakan bahwa ada keterampilan lain yang diperoleh di Poltekkes Kemenkes
Bengkulu yang bermanfaat bagi kemajuan karier.

Hasil wawancara dengan alumni menunjukkan keterampilan yang membantu pengembangan karier:

"Keterampilan yang sangat membantu saya dalam bekerja di tempat kerja adalah keterampilan mengoperasikan komputer, dulunya sebelum kuliah menghidup- 
kan komputer saja saya belum bisa”. (Ny. $M, T n . Y, N y . T$ ).

Di samping itu keterampilan lain yang membantu pengembangan karier alumni Poltekkes Kemenkes Bengkulu :

"Kalau saya sih keterampilan yang sangat membatu dalam bekerja adalah keterampilan presentasi di muka umum, dulu saya sangat takut kalau disuruh maju kedepan menyajikan makalah atau berbicara di depan orang banyak". (Ny. Y, Ny. L, Ny. N)

Hasil wawancara dengan alumni tentang mata kuliah yang bermanfaat dalam pekerjaan :

"Sebagai bidan, bagi saya mata kuliah asuhan kebidanan sangat bermanfaat bagi saya dalam menjalankan pekerjaan di tempat kerja dan menolong persalinan”. (Ny. M, Ny. N).

"Kalau saya sih mata kuliah asuhan keperawatan sangat bermanfaat bagi saya dalam bekerja karena kita selalu dituntut berpikir kritis dan rasional dalam setiap tindakan keperawatan walaupun dalam pembuatan dokumentasinya sangat ribet dan memakan waktu”. (Ny. A, Tn. T)

"Menurut Saya mata kuliah yang bermanfaat dalam bekerja adalah mata $\mathrm{ku}$ liah komputer". (Ny. R, Tn. B).

Hasil wawancara dengan alumni tentang mata kuliah yang tidak relevan dengan pekerjaan :

"Mata kuliah matematika tidak relevan dengan pekerjaan saya. Kalau menghitung atau membuat laporan keuangan saya biasanya pakai komputer atau kalkulator. Sebaikanya mata kuliah tersebut gak usah dimasukkan dalam mata kuliah di Poltekkes, gak relevan". (Ny. R, Ny. F, Ny. A).

Hasil wawancara dengan alumni tentang mata kuliah yang perlu ditambah pada kurikulum :

"Mata kuliah yang perlu ditambahkan di jurusan kebidanan adalah praktek lapangan, kebidanan dan patologi, dan metode pembelajaran”. (Ny. E, Ny. T, Ny. Y)

Tabel 2. Distribusi User/Pimpinan Berdasarkan Pendapat Tentang Penguasaan Kompetensi Lulusan Poltekkes Kemenkes Bengkulu Tahun 2011

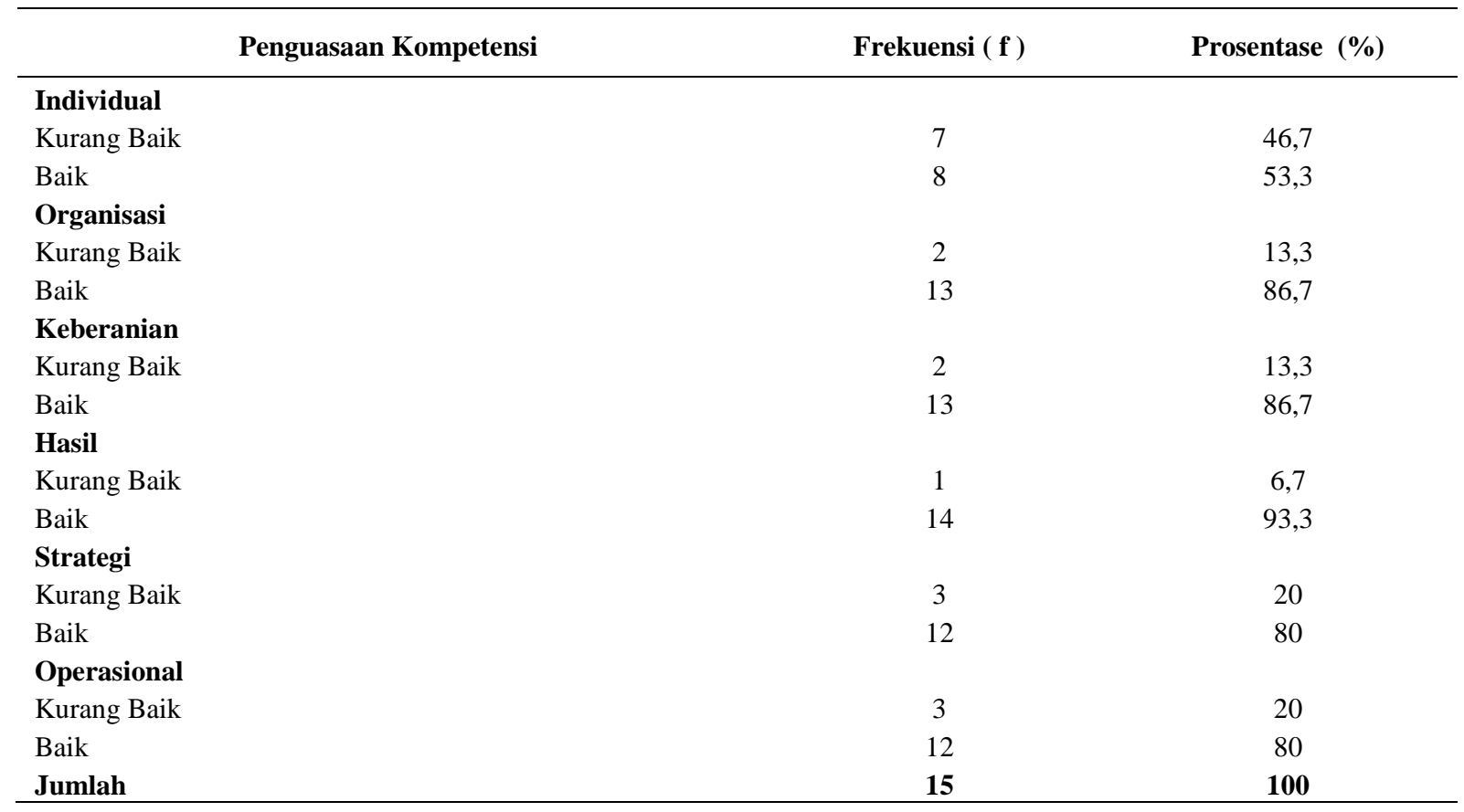

Tabel di atas menunjukkan bahwa separuh $(53,3 \%)$ user/pimpinan berpendapat bahwa penguasan kompetensi individual lulusan Poltekkes Kemenkes Bengkulu a- 
dalah baik, sebagian besar $(86,7 \%)$ berpendapat bahwa penguasan kompetensi organisasi adalah baik, sebagian besar $(86,7 \%)$ user berpendapat bahwa penguasan kompetensi keberanian adalah baik, hampir seluruh $(93,3 \%)$ berpendapat bahwa penguasaan kompetensi hasil adalah baik, sebagian besar $(80 \%)$ berpendapat bahwa penguasaan kompetensi strategi adalah baik, dan sebagian besar (80\%) user/pimpinan berpendapat bahwa penguasan kompetensi operasional adalah baik.

Hasil wawancara dengan rekan kerja tentang kemampuan yang dikuasai dengan baik oleh alumni Poltekkes Kemenkes Bengkulu adalah, sebagai berikut :

"Kemampuan yang dikuasi dengan baik oleh alumni Poltekkes Kemenkes Bengkulu adalah : mereka sangat percaya diri, cepat beradaptasi dengan lingkungan kerja, produktivitas kerja yang baik, mam- pu menerapkan dengan baik keahlian dalam pekerjaan, etos kerja baik, motivasi kerja tinggi, jujur dan disiplin dalam bekerja, kami sangat senang bekerjasama dengan lulusan Poltekkes Kemenkes Bengkulu”. (Rekan kerja dari Dinkes RL, Pukesmas Sumber Urip dan RSJKO)

Hasil wawancara dengan rekan kerja tentang kemampuan yang kurang dikuasai oleh alumni Poltekkes Kemenkes Bengkulu adalah, sebagai berikut :

“...yang kurang dikuasai oleh Alumni dari Poltekkes Kemenkes Bengkulu menurut saya adalah penguasan bahasa asing yang sangat kurang, mohon pihak Poltekkes dapat meningkatkan kemampuan mahasiswa pada saat pendidikan”. (Rekan kerja dari Puskesmas Dinkes RL, Puskesmas Sumber Urip, dan Puskesmas Ujan Mas)

Tabel 3. Distribusi User/Pimpinan Berdasarkan Pendapat Tentang Penguasaan Kompetensi Khusus Lulusan Poltekkes Kemenkes Bengkulu Tahun 2011

\begin{tabular}{|c|c|c|c|c|c|c|c|c|c|c|c|c|}
\hline \multirow[t]{2}{*}{ Kompetensi } & \multicolumn{2}{|c|}{$\begin{array}{c}\text { Tidak } \\
\text { Menguasai }\end{array}$} & \multicolumn{2}{|c|}{$\begin{array}{c}\text { Kurang } \\
\text { Menguasai }\end{array}$} & \multicolumn{2}{|c|}{$\begin{array}{c}\text { Cukup } \\
\text { Menguasai }\end{array}$} & \multicolumn{2}{|c|}{ Menguasai } & \multicolumn{2}{|c|}{$\begin{array}{c}\text { Sangat } \\
\text { Menguasai }\end{array}$} & \multicolumn{2}{|c|}{ Jumlah } \\
\hline & $\mathrm{F}$ & $\%$ & $\mathrm{~F}$ & $\%$ & $\mathrm{~F}$ & $\%$ & $\mathrm{~F}$ & $\%$ & $\mathrm{~F}$ & $\%$ & $\mathbf{F}$ & $\%$ \\
\hline Pengetahuan Umum & - & - & - & - & 11 & 73,3 & 4 & 26,7 & - & - & 15 & 100 \\
\hline Bahasa Inggris & 3 & 20 & 6 & 40 & 5 & 33,3 & 1 & 6,7 & - & - & 15 & 100 \\
\hline Komputer & - & - & 5 & 33,3 & 8 & 53,4 & 2 & 13,3 & - & - & 15 & 100 \\
\hline Metodologi Penelitian & - & - & 4 & 26,7 & 9 & 60 & 2 & 13,3 & - & - & 15 & 100 \\
\hline Kerjasama Tim & - & - & & & 13 & 86,7 & 2 & 13,3 & - & - & 15 & 100 \\
\hline $\begin{array}{l}\text { Keterampilan Komunikasi } \\
\text { Lisan }\end{array}$ & - & - & 1 & 6,6 & 10 & 66,7 & 4 & 26,7 & - & - & 15 & 100 \\
\hline $\begin{array}{l}\text { Keterampilan Komunikasi } \\
\text { Tertulis }\end{array}$ & - & - & 2 & 13,3 & 8 & 53,4 & 5 & 33,3 & - & - & 15 & 100 \\
\hline $\begin{array}{l}\text { Proses Pemberdayaan Ma- } \\
\text { syarakat }\end{array}$ & - & - & 3 & 20 & 9 & 60 & 3 & 20 & - & - & 15 & 100 \\
\hline Manajemen Organisasi & - & - & 2 & 13,3 & 12 & 80 & 1 & 6,7 & - & - & 15 & 100 \\
\hline Kepemimpinan & - & - & 4 & 26,7 & 10 & 66,7 & 1 & 6,6 & - & - & 15 & 100 \\
\hline Manajemen Keuangan & - & - & 2 & 13,3 & 11 & 73,3 & 1 & 6,7 & 1 & 6,7 & 15 & 100 \\
\hline
\end{tabular}

Tabel di atas menunjukkan bahwa sebagian besar $(73,3 \%)$ user/pimpinan berpendapat bahwa lulusan Poltekkes Kemenkes Bengkulu cukup menguasai pengetahuan umum, hampir separuh $(40 \%)$ berpendapat bahwa lulusan Poltekkes Kemenkes Bengkulu kurang menguasai bahasa Inggris, separuh $(53,4 \%)$ berpendapat bahwa lulusan Poltekkes Kemenkes Bengkulu cukup menguasai komputer, lebih dari se- paruh $(60 \%)$ berpendapat bahwa lulusan Poltekkes Kemenkes Bengkulu cukup menguasai metodologi penelitian, sebagian besar $(86,7 \%)$ berpendapat bahwa lulusan Poltekkes Kemenkes Bengkulu cukup menguasai kerjasama tim, lebih dari separuh $(66,7 \%)$ berpendapat bahwa lulusan Poltekkes Kemenkes Bengkulu cukup menguasai keterampilan komunikasi lisan, separuh $(53,4 \%)$ berpendapat bahwa lulusan 
Poltekkes Kemenkes Bengkulu cukup menguasai keterampilan komunikasi tertulis, lebih dari separuh $(60 \%)$ berpendapat bahwa lulusan Poltekkes Kemenkes Bengkulu cukup menguasai proses pemberdayaan masyarakat, sebagian besar (80\%) berpendapat bahwa lulusan Poltekkes Kemenkes Bengkulu cukup menguasai manajemen organisasi, lebih dari separuh $(66,7 \%)$ berpendapat bahwa lulusan Poltekkes Kemenkes Bengkulu cukup menguasai kompetensi kepemimpinan, dan sebagian besar $(73,3 \%)$ user/pimpinan berpendapat bahwa lulusan Poltekkes Kemenkes Bengkulu cukup menguasai manajemen keuangan.

Hasil penelitian diatas yang menunjukkan bahwa lulusan kurang menguasai bahasa Inggris juga didukung oleh hasil wawancara terhadap rekan kerja, sebagai berikut :

"Umumnya yang perlu ditingkatkan dari lulusan Poltekkes Kemenkes Bengkulu adalah kemampuan dalam bahasa asing, lebih kreatif dan mempunyai inovasi, serta lebih care terhadap pasien”. (Tn. E, Ny. R)

Tabel 4. Distribusi User/Pimpinan Berdasarkan Pendapat Tentang Kompetensi Yang Dibutuhkan Terhadap Lulusan Poltekkes Kemenkes Bengkulu Tahun 2011

\begin{tabular}{|c|c|c|c|c|c|c|c|c|c|c|c|c|}
\hline \multirow[t]{2}{*}{ Kompetensi } & \multicolumn{2}{|c|}{$\begin{array}{l}\text { Tidak Di- } \\
\text { butuhkan }\end{array}$} & \multicolumn{2}{|c|}{$\begin{array}{c}\text { Kurang } \\
\text { Dibutuhkan }\end{array}$} & \multicolumn{2}{|c|}{$\begin{array}{l}\text { Cukup Di- } \\
\text { butuhkan }\end{array}$} & \multicolumn{2}{|c|}{ Dibutuhkan } & \multicolumn{2}{|c|}{$\begin{array}{l}\text { Sangat Di- } \\
\text { butuhkan }\end{array}$} & \multicolumn{2}{|c|}{ Jumlah } \\
\hline & $\mathrm{F}$ & $\%$ & $\mathrm{~F}$ & $\%$ & $\mathrm{~F}$ & $\%$ & $\mathrm{~F}$ & $\%$ & $\mathrm{~F}$ & $\%$ & $\mathbf{F}$ & $\%$ \\
\hline Pengetahuan Umum & - & - & - & - & 4 & 26,7 & 7 & 46,6 & 4 & 26,7 & 15 & 100 \\
\hline Bahasa Inggris & - & - & 2 & 13,3 & 4 & 26,7 & 6 & 40 & 3 & 20 & 15 & 100 \\
\hline Komputer & - & - & - & - & 3 & 20 & 8 & 53,3 & 4 & 26,7 & 15 & 100 \\
\hline Met. Penelitian & - & - & - & - & 3 & 20 & 9 & 60 & 3 & 20 & 15 & 100 \\
\hline Kerjasama Tim & - & - & - & - & 1 & 6,7 & 8 & 53,3 & 6 & 40 & 15 & 100 \\
\hline $\begin{array}{l}\text { Keterampilan Komuni- } \\
\text { kasi Lisan }\end{array}$ & - & - & - & - & 1 & 6,6 & 7 & 46,7 & 7 & 46,7 & 15 & 100 \\
\hline $\begin{array}{l}\text { Keterampilan Komuni- } \\
\text { kasi Tertulis }\end{array}$ & - & - & - & - & 1 & 6,7 & 9 & 60 & 5 & 33,3 & 15 & 100 \\
\hline $\begin{array}{l}\text { Proses Pemberdayaan } \\
\text { Masyarakat }\end{array}$ & - & - & - & - & 1 & 6,6 & 7 & 46,7 & 7 & 46,7 & 15 & 100 \\
\hline Manajemen Organisasi & - & - & - & - & 2 & 13,3 & 9 & 60 & 4 & 26,7 & 15 & 100 \\
\hline Kepemimpinan & - & - & - & - & 3 & 20 & 7 & 46,7 & 5 & 33,3 & 15 & 100 \\
\hline Manajemen Keuangan & - & - & - & - & 4 & 26,7 & 6 & 40 & 5 & 33,3 & 15 & 100 \\
\hline
\end{tabular}

Tabel di atas menunjukkan bahwa hampir separuh $(46,6 \%)$ user/pimpinan berpendapat kompetensi pengetahuan umum dibutuhkan dari lulusan Poltekkes Kemenkes Bengkulu, hampir separuh (40\%) berpendapat kompetensi bahasa Inggris dibutuhkan dari lulusan Poltekkes Kemenkes Bengkulu, separuh $(53,3 \%)$ berpendapat kompetensi komputer dibutuhkan dari lulusan Poltekkes Kemenkes Bengkulu, lebih dari separuh (60\%) berpendapat kompetensi metodologi penelitian dibutuhkan dari lulusan Poltekkes Kemenkes Bengkulu, separuh $(53,3 \%)$ berpendapat kompetensi kerjasama tim dibutuhkan dari lulusan Poltekkes Kemenkes Bengkulu, hampir separuh $(46,7 \%)$ berpendapat kompetensi keterampilan komunikasi lisan sa- ngat dibutuhkan dari lulusan Poltekkes Kemenkes Bengkulu, lebih dari separuh $(60 \%)$ berpendapat kompetensi keterampilan komunikasi tertulis dibutuhkan dari lulusan Poltekkes Kemenkes Bengkulu, hampir separuh $(46,7 \%)$ berpendapat kompetensi proses pemberdayaan masyarakat sangat dibutuhkan dari lulusan Poltekkes Kemenkes Bengkulu, lebih dari separuh (60\%) berpendapat kompetensi manajemen dan organisasi dibutuhkan dari lulusan Poltekkes Kemenkes Bengkulu, hampir separuh $(46,7 \%)$ berpendapat kompetensi kepemimpinan dibutuhkan dari lulusan Poltekkes Kemenkes Bengkulu, dan hampir separuh (40\%) user/pimpinan berpendapat bahwa kompetensi penguasaan manajemen ke- 
uangan dibutuhkan dari lulusan Poltekkes Kemenkes Bengkulu.

Hasil penelitian di atas yang menunjukkan bahwa kompetensi yang sangat dibutuhkan pimpinan institusi tempat lulusan bekerja melalui kuesioner salah satunya adalah kerjasama tim dan keterampilan komunikasi lisan, juga diungkapkan oleh pimpinan pada saat wawancara, sebagi berikut :

"Hal-hal yang perlu dibekali pada lulusan Poltekkes Kemenkes Bengkulu adalah keterampilan, komunikasi, kerjasama, penguasaan ilmu, motivasi dan kreativitas". (Ny. EE dan Tn. B)
Hasil wawancara dengan alumni tentang kompetensi yang sangat diperlukan adalah sebagai berikut :

"Kompetensi yang sangat dibutuh-kan oleh alumni Poltekkes Kemenkes Bengkulu khususnya bagi kami adalah pe-ngetahuan umum, komputer dan kepemim-pinan". (Ny. R, Ny. W)

Gambaran Mutu Lulusan Lulusan Poltekkes Kemenkes Bengkulu

Gambaran pendapat pimpinan dan rekan kerja terhadap mutu lulusan Poltek-kes Kemenkes Bengkulu dapat dilihat pada tabel berikut ini.

Tabel 5. Distribusi Responden Berdasarkan Pendapat tentang Mutu Lulusan Poltekkes Kemenkes Bengkulu Tahun 2011

\begin{tabular}{lccc}
\hline & Mutu Lulusan & Frekuensi (f) & Prosentase (\%) \\
\hline Kurang & 4 & 36,4 \\
Baik & 7 & 63,6 \\
Jumlah & $\mathbf{1 1}$ & $\mathbf{1 0 0}$ \\
\hline
\end{tabular}

Berdasarkan tabel di atas dapat diketahui bahwa lebih dari separuh $(63,6 \%)$ responden berpendapat mutu lulusan Poltekkes Kemenkes Bengkulu adalah baik.

Hasil wawancara dengan pimpinan tentang mutu Lulusan Poltekkes Kemenkes Bengkulu menunjukkan lebih dari separuh berpendapat bahwa mutu/kinerja lulusan tersebut baik, dimana pendapat sebagian pimpinan tersebut, sebagai berikut :

"Jika dibandingkan dengan aulmni non Poltekkes, alumni dari Poltekkes Kemenkes Bengkulu cukup membanggakan, lebih terampil dan lebih baik". (Pimpinan Puskesmas Ujan Mas, Puskemas Bangun Jaya, dan Puskesmas Sukamerindu).

Tabel 6. Distribusi Rekan Kerja Berdasarkan Pendapat tentang Mutu Secara Keseluruhan Lulusan Poltekkes Kemenkes Bengkulu Tahun 2011

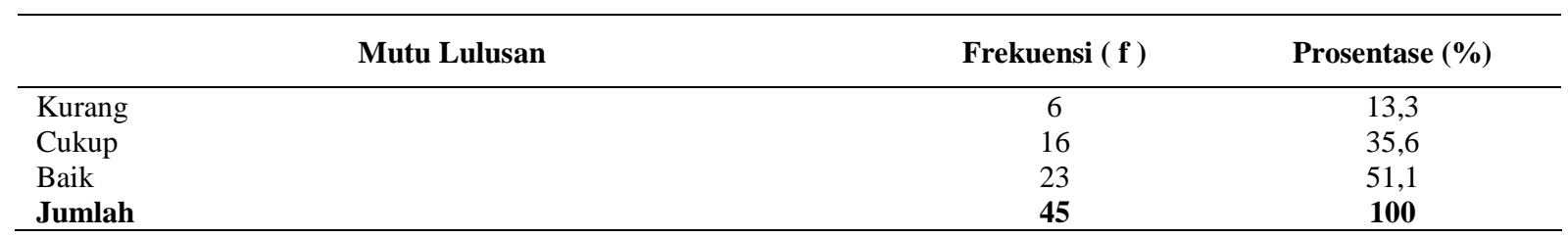

Berdasarkan tabel di atas dapat diketahui bahwa separuh $(51,1 \%)$ rekan kerja berpendapat mutu secara keseluruhan lulusan Poltekkes Kemenkes Bengkulu adalah baik. Demikian juga dengan hasil wawancara dengan 45 orang rekan kerja tentang mutu/kinerja lulusan Poltekkes Kemenkes Bengkulu, lebih dari separuh berpendapat bahwa mutu/kinerja lulusan tersebut baik, dimana pendapat sebagian rekan kerja tersebut, sebagai berikut :

"SDM lulusan Poltekkes Kemenkes Bengkulu mampu bersaing dengan lulusan non Poltekkes. Lumayan memuaskan kinerja lulusan poltekkes dibanding dengan lulusan lain”. (Tn. A, Ny. Y, Ny. YR) 
Kepuasaan User (Institusi Pengguna) Terhadap Lulusan Poltekkes Kemenkes Bengkulu
Gambaran kepuasan user terhadap lulusan Poltekkes Kemenkes Bengkulu dapat dilihat pada tabel berikut ini.

Tabel 7. Distribusi Responden Berdasarkan Kepuasan Terhadap Lulusan Poltekkes Kemenkes Bengkulu Tahun 2011

\begin{tabular}{clccc}
\hline \multirow{2}{*}{ No. } & & Kepuasan & $\begin{array}{c}\text { Frekuensi } \\
(\mathbf{f})\end{array}$ & $\begin{array}{c}\text { Prosentase } \\
(\boldsymbol{\%})\end{array}$ \\
\hline 1. & Tidak Puas & 3 & 27,3 \\
2. & Puas & 8 & 72,7 \\
& Jumlah & $\mathbf{1 1}$ & $\mathbf{1 0 0}$ \\
\hline
\end{tabular}

Berdasarkan tabel 7. di atas dapat diketahui bahwa sebagian besar $(72,7 \%)$ responden puas dengan kinerja lulusan Poltekkes Kemenkes Bengkulu.

Hasil wawancara terhadap pimpinan terungkap bahwa dari 15 orang pimpinan tempat lulusan Poltekkes Kemenkes Bengkulu bekerja sebagian besar puas terhadap kinerja lulusan tersebut, sebagaimana yang dikemukakan oleh sebagian besar pimpinan, sebagai berikut :

"Saya cukup puas dengan kinerja lulusan dari Poltekkes Kemenkes Bengkulu karena lulusannya rajin, pengetahuannya baik, disiplin, terampil, ramah, cepat beradaptasi, dan sopan santun. Kami mengharapkan terus mendapatkan formasi dari lulusan Poltekkes Kemenkes Bengkulu". (Tn. S, Ny. E, Tn. B).

Hasil wawancara terhadap rekan ker-ja lulusan Poltekkes Kemenkes Bengkulu terungkap bahwa lebih dari separuh puas terhadap kinerja lulusan Poltekkes, sebagaimana yang dikemukan oleh rekan kerja lulusan tersebut, sebagai berikut :

"Kami umumnya puas dengan kiner-ja teman kami tamatan dari Poltekkes Kemenkes Bengkulu. Dalam melaksanakan tugas dapat diselesaikan dengan baik, dapat bekerja sama dengan tim, disiplin, dan sebagian lulusan Poltekkes Kemenkes Bengkulu ada yang berprestasi dan cekatan dalam melakukan tindakan". (Tn. E, Ny. F dan Ny. YR).
Hasil wawancara dengan pimpinan/ user tentang karakter kerja alumni Poltekkes Kemenkes Bengkulu yang membuat pimpinan puas adalah sebagai berikut :

"Karakter yang membuat Saya puas dengan kinerja alumni Poltekkes Kemenkes Bengkulu adalah terampil, disiplin, dan sistematis dalam bekerja". (Pimpinan Puskesmas Bangun Jaya, Puskesmas Betungan dan Puskesmas Sukamerindu)

Hasil wawancara dengan rekan kerja tentang karakter kerja alumni Poltekkes Kemenkes Bengkulu yang membuat mereka puas adalah sebagai berikut :

“...Yang membuat kami puas bekerja dengan alumni Poltekkes adalah cara kerja lulusan Poltekkes Kemenkes Bengkulu tanggap dan sistematis, disiplin dan mampu untuk beradaptasi dengan lingkungan kerja”. (Rekan Kerja dari Puskesmas Curup Timur dan Sukamerindu)

\section{Posisi Lulusan Poltekkes Kemenkes Beng- kulu Pada Jendela Pelanggan (Customer Window)}

Bagan berikut ini menggambarkan ekspektasi pelanggan pengguna lulusan Poltekkes Kemenkes Bengkulu pada jendela pelanggan (Customer Window) berdasarkan jendela pelanggan yang perkenalkan oleh ARBOR Inc. Philadelphia. 


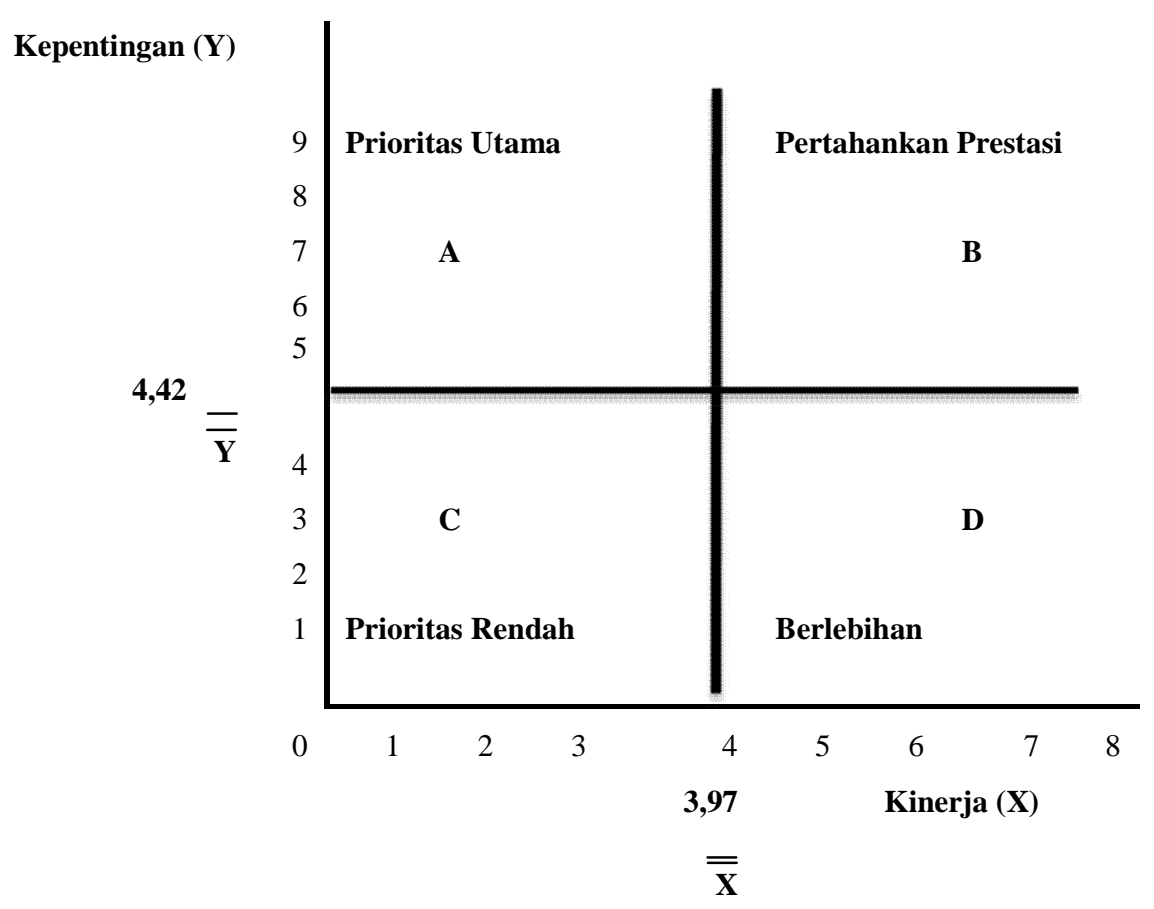

Gambar 1. Jendela Pelanggan (Customer Window) Poltekkes Kemenkes Bengkulu Tahun 2011

Berdasarkan hasil analisis korelasi data kualitatif untuk mengetahui seberapa dekat hubungan antara faktor-faktor/atribut dengan kepuasan pelanggan pengguna lulusan Poltekkes Kemenkes Bengkulu pada bagan 4.1 di atas didapatkan bahwa nilai $\mathbf{X}$ $=\mathbf{3 , 9 7}$ dan nilai $Y=\mathbf{4 , 4 2}$.
Kuadran posisi faktor-faktor yang mempengaruhi kepuasan pelanggan pengguna lulusan Poltekkes Kemenkes Bengkulu (berdasarkan pertanyaan-pertanyaan pada kuesioner kepuasan user/rekan kerja) dapat dilihat pada tabel berikut ini.

Tabel 8. Kwadran Posisi Faktor-faktor Yang Mempengaruhi Kepuasan Pelanggan Pengguna Lulusan Poltekkes Kemenkes Bengkulu Tahun 2011

\begin{tabular}{cccccccccccc}
\hline Nomor & 1 & 2 & 3 & 4 & 5 & 6 & 7 & 8 & 9 & 10 \\
\hline Kwadran & A & A & B & C & C & C & B & C & D & B \\
Nomor & 11 & 12 & 13 & 14 & 15 & 16 & 17 & 18 & 19 & 20 \\
Kwadran & A & A & B & B & D & B & C & A & A & B \\
Nomor & 21 & 22 & 23 & 24 & 25 & 26 & 27 & 28 & 29 & 30 \\
Kwadran & C & D & B & B & A & A & B & C & C & A \\
Nomor & 31 & 32 & 33 & 34 & 35 & 36 & 37 & 38 & 39 & 40 \\
Kwadran & C & C & D & B & B & B & C & C & C & B \\
\hline
\end{tabular}

Tabel diatas menunjukkan bahwa terdapat 9 faktor (nomor : 1, 2, 11, 12, 18, 19, 25, 26, dan 30) yang berada di kuadran A, 14 faktor (nomor : 3, 7, 10, 13, 14, 16, $20,23,24,27,34,35,36$, dan 40) yang berada di kuadran B, 13 faktor (nomor : 4, 5, $6,8,17,21,28,29,31,32,37,38$, dan 39) yang berada di kuadran $\mathrm{C}$, dan terdapat 4 faktor (nomor : 9, 15, 22, 33, ) yang berada di kuadran D.

\section{Gambaran Masa Tunggu Lulusan Untuk Mendapatkan Pekerjaan}

Mahasiswa yang mengikuti pendidikan di Poltekkes Kemenkes Bengkulu sebelumnya ada yang telah bekerja. Pada pe- 
nelitian ini, terdapat beberapa orang mahasiswa yang telah bekerja sebagai PNS sebelum melanjutkan pendidikan. Gambaran lama masa tunggu lulusan Poltekkes Ke- menkes Bengkulu dalam mendapatkan pekerjaan setelah menyelesaikan pendidikan adalah sebagai berikut.

Tabel 9. Distribusi Lulusan Poltekkes Kemenkes Bengkulu Berdasarkan Masa Tunggu Untuk Mendapatkan Pekerja Tahun 2011

\begin{tabular}{|c|c|c|}
\hline Lama Masa Tunggu & Frekuensi ( f ) & Prosentase $(\%)$ \\
\hline$<3$ bulan & 36 & 23,4 \\
\hline 3- 6 bulan & 36 & 23,4 \\
\hline 7-9 bulan & 8 & 5,2 \\
\hline 10-12 bulan & 5 & 3,2 \\
\hline 12 bulan & 3 & 1,9 \\
\hline$>12$ bulan & 8 & 5,2 \\
\hline Sudah Bekerja & 58 & 37,7 \\
\hline Jumlah & 154 & 100 \\
\hline
\end{tabular}

Tabel di atas menunjukkan bahwa sebagian kecil $(37,7 \%)$ responden sudah bekerja sebelum mengikuti pendidikan di Poltekkes Kemenkes Bengkulu, (23,4\%) mendapatkan pekerjaan < 3 bulan dan $(23,4 \%)$ responden mendapatkan pekerjaan 3-6 bulan setelah lulus dari Poltekkes Kemenkes Bengkulu.

Tabel 10. Distribusi Lulusan Poltekkes Kemenkes Bengkulu Berdasarkan Tempat Kerja Tahun 2011

\begin{tabular}{|c|c|c|}
\hline Lama Masa Tunggu & Frekuensi ( f ) & Prosentase $(\%)$ \\
\hline PNS & 128 & 83,1 \\
\hline Swasta & 2 & 1,3 \\
\hline Pegawai Tetap & 1 & 0,7 \\
\hline Pegawai Kontrak & 3 & 1,9 \\
\hline PTT & 8 & 5,2 \\
\hline Honorer BPS & 2 & 1,3 \\
\hline Honorer Puskesmas & 10 & 6,5 \\
\hline Jumlah & 154 & 100 \\
\hline
\end{tabular}

Tabel di atas menunjukkan bahwa sebagian besar $(83,1 \%)$ lulusan Poltekkes Kemenkes Bengkulu bekerja sebagai PNS dan sebagian kecil $(6,5 \%)$ Honorer di Puskesmas dan sebagian kecil $(5,2 \%)$ bekerja sebagai Pegawai Tidak Tetap (PTT) di daerah terpencil.

Hasil wawancara dengan alumni tentang pendapat perbulan, umumnya menjawab lebih dari Rp. 2.000.000,-. Hasil wawancara dengan sebagian besar alumni adalah sebagai berikut :

"Setelah menamatkan pendidikan di Poltekkes Kemenkes Bengkulu dan bekerja, pendapatan saya perbulan sekarang berkisar di atas dua juta rupiah". (Ny. S, Tn. B, Ny. WL)

Hasil wawancara dengan alumni tentang pendapat mereka apakah kompetensi yang diperoleh di Poltekkes Kemenkes Bengkulu membantu memperoleh pekerjaan, adalah sebagai berikut :

"Kompetensi yang saya miliki di Poltekkes Kemenkes Bengkulu dan ijazah yang saya peroleh, sangat membatu saya mendapatkan pekerjaan”. (Ny. S, Ny. K, Ny. N).

\section{Gambaran Faktor-Faktor Yang Diduga Berhubungan Dengan Ketidakpuasan User Terhadap Lulusan Poltekkes Kemenkes Bengkulu}

Berdasarkan posisi faktor-faktor yang diduga berhubungan dengan kepuasan pelanggan pada jendela pelanggan (Customer Window), maka dapat disim-pulkan bahwa faktor-faktor berada di kuadran A yang terdiri dari 9 faktor (nomor: 1, 2, 11, 12, 
$18,19,25,26$, dan 30) diduga berhubungan dengan ketidapuasan user terhadap lulusan Poltekkes Kemenkes Bengkulu. Adapun faktor-faktor tersebut adalah sebagai berikut :

1. Memberikan pelayanan dengan tepat sesuai dengan yang dijanjikan (1)

2. Mengembangkan hubungan saling percaya dengan pelanggan, rekan kerja dan atasan (2)

3. Menjaga peralatan kerja dalam keadaan bersih dan tertata rapi (11)

4. Menjalankan jadwal pelayanan tepat waktu (12)

5. Cepat tanggap menyelesaikan keluhan pelanggan/rekan kerja (18)

6. Memberikan pelayanan dengan pengetahuan yang baik (19)

7. Bersikap luwes dan supel (25)

8. Mampu beradaptasi dan mengembangkan diri dengan cepat (26)

9. Disiplin terhadap waktu dan pekerjaan (30

\section{PEMBAHASAN}

Pada pembahasan akan diuraikan tentang makna hasil penelitian serta membandingkanya dengan teori, mendiskusikan hasil penelitian yang telah diuraikan pada bab hasil, dan menjelaskan keterbatasan penelitian. Sesuai dengan tujuan penelitian yang diajukan dalam penelitian ini, maka pembahasan hasil penelitian diarahkan pada enam tujuan khusus.

Kesesuaian Kurikulum Dan Pemanfaatan Kompetensi Lulusan Terhadap Kebutuhan User (Institusi Pengguna)

Hasil penelitian menunjukkan bahwa hampir separuh $(46,8 \%)$ lulusan menyatakan bahwa ilmu yang diperoleh di Poltekkes Kemenkes Bengkulu relevan dengan peningkatan karier, dan lebih dari separuh $(57,1 \%)$ lulusan menyatakan bahwa ada keterampilan lain yang diperoleh di Poltekkes Kemenkes Bengkulu yang bermanfaat bagi kemajuan karier.
Hasil penelitian tersebut mengindikasikan bahwa kurikulum di Jurusan Poltekkes Kemenkes Bengkulu sangat terkait dengan pekerjaan yang mereka tekuni saat ini. Adapun lulusan Poltekkes Kemenkes Bengkulu berasal dari jurusan Keperawatan, Kebidanan, dan Gizi yang bekerja di berbagai instansi kesehatan di berbagai tempat di Propinsi Bengkulu dan propinsi sekitarnya. Beberapa lulusan dari jurusan kebidanan dan keperawatan bekerja di pelayanan kesehatan nasional seperti di Jakarta dan Bandung bahkan ada beberapa orang lulusan yang bekerja di luar negeri.

Menurut Asmawi (2005) kurikulum adalah seperangkat rencana dan pengaturan mengenai isi maupun bahan kajian dan pelajaran serta cara penyampaian dan penilaiannya yang digunakan sebagai pedoman penyelenggaraan kegiatan belajar mengajar di perguruan tinggi. Kurikulum dibagi dalam kurikulum inti dan kurikulum lokal (institusional). Kurikulum inti adalah bagian dari kurikulum pendidikan tinggi yang berlaku secara nasional untuk setiap program studi, yang memuat tujuan pendidikan, isi pengetahuan, dan kemampuan minimal yang harus dicapai peserta didik, dalam penyelesaian suatu program studi. Disisi lain kurikulum lokal (institusional) adalah bagian dari kurikulum pendidikan tinggi yang berkenaan dengan keadaan dan kebutuhan lingkungan serta ciri khas perguruan tinggi yang bersangkutan.

Untuk mengembangkan kurikulum pendidikan tinggi, perguruan tinggi yang bersangkutan mengacu pada standar nasional pendidikan untuk setiap program studi. Kerangka dasar dan struktur kurikulum pendidikan tinggi dikembangkan oleh perguruan tinggi yang bersangkutan dengan mengacu pada standar nasional pendidikan untuk setiap program studi. (Pasal 38 ayat 3 dan 4 UU RI Nomor 20 Tahun 2003). Mengenai pengembangan kurikulum ini, disusun sesuai dengan jenjang pendidikan dalam kerangka Negara kesatuan Republik Indonesia dengan memperhatikan: peningkatan iman dan takwa, peningkatan akhlak mulia, peningkatan potensi, kecerdasan 
dan minat peserta didik, keragaman potensi daerah dan lingkungan, tuntutan pembangunan daerah dan nasional, tuntutan dunia kerja, perkembangan ilmu pengetahuan, teknologi dan seni, agama, dinamika perkembangan global, dan persatuan nasional dan nilai-nilai kebangsaan (Asmawi, 2005)

Kurikulum yang dipakai di Jurusan Poltekkes Kemenkes Bengkulu terdiri dari kurikulum inti dan muatan lokal (mulok). Kurikulum inti berasal dari Pusat Pendidikan Tenaga Kesehatan Kemenkes RI. Sedangkan kurikulum muatan lokal disesuaikan dengan kondisi daerah setempat dan mengutamakan pada permintaan pasar kerja tempat tujuan lulusan ditempatkan atau permintaan institusi yang menjalin kerjasama dengan jurusan di Poltekkes Kemenkes Bengkulu. Sebagai contoh, Prodi Keperawatan Bengkulu Jurusan Keperawatan memasukkan mulok gawat dan siaga bencana serta bahasa Inggris ke dalam kurikulum institusinya. Hal ini dilakukan dengan pertimbangan bahwa kondisi daerah Bengkulu yang rawan bencana gempa dan Tsunami. Mulok bahasa Inggris di diberikan karena lulusan diharapkan dapat bekerja di rumah sakit-rumah sakit Internasional yang berada di dalam maupun luar negeri (Arab Saudi, Qatar, Jepang, dan Amerika).

Kemajuan karier lulusan sangat tergantung kepada muatan kurikulum yang sesuai dengan kondisi tempat kerja, dimana lulusan sudah disiapkan untuk menghadapi kondisi tempat kerja. Contoh konkrit, lulusan mahasiswa Jurusan Kebidanan harus dibekali dengan kemampuan komunikasi, kerjasama dalam tim, pengorganisasian dan pemberdayaan masyarakat, dan kepemimpinan agar dapat bekerja di desa dimana umumnya lulusan bekerja sebagai bidan PTT. Hasil penelitian menunjukkan bahwa $31,2 \%$ lulusan menyatakan keterampilan atau muatan tambahan yang membantu pengembangan karier adalah keterampilan mengoperasikan komputer.

Hasil penelitian menunjukkan bahwa hampir seluruh $(93,3 \%)$ user/pimpinan berpendapat bahwa penguasaan kompetensi hasil adalah baik. Kompetensi hasil yang merupakan kompetensi individual terdiri dari kompetensi berorientasi pada tindakan dan mengarah pada hasil. Hasil ini menunjukkan bahwa lulusan Poltekkes Kemenkes Bengkulu lebih menguasai keterampilan/skill praktek dan menunjukkan hasil pekerjaan dengan baik.

Hasil penelitian menunjukkan bahwa hampir separuh $(40 \%)$ user/pimpinan berpendapat bahwa lulusan Poltekkes Kemenkes Bengkulu kurang menguasai bahasa Inggris. Hal ini menunjukkan bahwa Poltekkes Kemenkes Bengkulu harus lebih meningkatkan kompetensi atau kemampuan Bahasa Inggris mahasiswa melalui kebijakan penambahan jumlah SKS muatan lokal Bahasa Inggris dan kursus Bahasa Inggris di luar jam kuliah pada setiap jurusan, agar lulusan mampu berkomunikasi dalam bahasa tersebut dengan baik. Hal tersebut mengantisipasi visi Prodi Keperawatan Bengkulu Jurusan Keperawatan yang akan mengirimkan lulusannya ke pasar kerja global maupun pasar kerja nasional pada rumah sakit Internasional.

Hasil penelitian didukung oleh pendapat Mitrani (1995, dalam Kurniawan, 2011) bahwa kompetensi adalah sebagai suatu sifat dasar seseorang yang dengan sendirinya berkaitan dengan pelaksanaan suatu pekerjaan secara efektif atau sangat berhasil (and underlying charactheristic: of an individual which is casually related to effective or superior performance in job). Ketidaksamaan dalam kompetensikompetensi inilah yang membedakan seseorang pelaku unggul dari perilaku yang berprestasi rata-rata. Untuk mencapai kinerja sekedar cukup atau rata-rata, diperlukan kompetensi batas (threshold competencies) atau kompetensi essensial.

Kompetensi batas atau kompetensi istimewa untuk suatu pekerjaan tertentu merupakan pola atau pedoman dalam pemilihan karyawan (personel selection), Perencanaan pengalihan tugas (succestion planing), peniliaian kinerja (performance appraisal), dan pengembangan.

Menurut Djafar (2011), kompetensi adalah spesifikasi dari pengetahuan dan ke- 
terampilan serta penerapan dari pengetahuan dan keterampilan tersebut dalam suatu pekerjaan atau suatu perusahaan sesuai dengan standar kinerja yang disyaratkan.

Kompentensi seorang individu merupakan sesuatu yang melekat dalam dirinya yang dapat digunakan untuk memprediksi tingkat kinerjanya. Sesuatu yang dimaksud bisa menyangkut motif, konsep diri, sifat, pengetahuan maupun kemampuan/keahlian. Kompentensi individu yang berupa kemampuan dan pengetahuan bisa dikembangkan melalui pendidikan dan pelatihan (Kurniawan, 2011).

Berdasarkan pendapat-pendapat di atas, agar lulusan dapat lulus dan diterima pada proses seleksi dan bekerja dengan baik pada intitusi/instansi yang mereka inginkan maka perguruan tinggi termasuk Poltekkes Kemenkes Bengkulu harus mempersiapkan kompetensi mahasiswa sesuai dengan keinginan pasar kerja. Hasil penelitian menunjukkan bahwa hampir separuh $(46,7 \%)$ user/pimpinan berpendapat kompetensi keterampilan komunikasi lisan dan pemberdayaan masyarakat sangat dibutuhkan dari lulusan Poltekkes Kemenkes Bengkulu. Hal ini dapat dipahami karena banyak lulusan Poltekkes Kemenkes Bengkulu yang bekerja di desa (baik di Puskesmas, Pustu, Polindes, dan lain-lain) sehingga kompetensi tersebut sangat dibutuhkan oleh pimpinan agar lulusan tersebut mampu mandiri dalam menghadapi, menggerakkan dan memberdayakan masyarakat. Poltekkes Kemenkes Bengkulu sebagai institusi penghasil lulusan harus memperhatikan masukan/saran dari pimpinan tempat lulusan mereka bekerja sehingga dapat memberikan kepuasan kepada user/pimpinan yang menggunakan jasa lulusan Poltekkes Kemenkes Bengkulu.

\section{Mutu Lulusan Lulusan Poltekkes Kemenkes Bengkulu}

Hasil penelitian menunjukkan bahwa lebih dari separuh $(63,6 \%)$ user berpendapat mutu lulusan Poltekkes Kemenkes Bengkulu adalah baik. Hasil penelitian ju- ga menunjukkan bahwa separuh $(51,1 \%)$ rekan kerja berpendapat mutu secara keseluruhan lulusan Poltekkes Kemenkes Bengkulu adalah baik. Berdasarkan hasil penelitian, dapat disimpulkan bahwa lulusan Poltekkes Kemenkes Bengkulu memiliki keistimewamaan dari lulusan lain, memenuhi standar sebagai seorang lulusan Poltekkes Kemenkes, memiliki sedikit kekurangan, dan dapat memenuhi kebutuhan atau keinginan pelanggan yang dalam hal ini adalah adalah pimpinan dan rekan kerja di mana lulusan bekerja.

Hasil penelitian sejalan dengan pendapat ISO (International Organization for Standardization) 8402, dalam Gaspersz, 2003) bahwa mutu dalam berarti totalitas dari karakteristik suatu produk yang menunjang kemampuannya untuk memuaskan kebutuhan yang dispesifikan atau ditetapkan. Mutu sering kali diartikan sebagai kepuasan pelanggan. Demikian juga menurut Juran (1989, dalam Wijono, 2000) mengemukakan bahwa: mutu sebagai keistimewaan produk. Di mata pelanggan, semakin baik keistimewaan produk semakin tinggi mutunya. Mutu berarti bebas dari kekurangan, di mata pelanggan semakin sedikit kekurangan, semakin baik mutunya.

Berdasarkan pengertian tentang mutu tersebut di atas, tampak bahwa mutu selalu berfokus kepada pelanggan (customer focused quality). Dengan demikian produkproduk didesain, diproduksi, serta pelayanan diberikan untuk memenuhi keinginan pelanggan. Karena mutu mengacu kepada segala sesuatu yang menentukan kepuasan pelanggan, suatu produk yang dihasilkan atau pelayanan yang diberikan baru dapat dikatakan bermutu apabila sesuai dengan keinginan pelanggan, dapat dimanfaatkan dengan baik, serta diproduksi atau dihasilkan dengan cara yang benar (Gaspersz, 2003).

Poltekkes Kemenkes Bengkulu sebagai perguruan tinggi yang terus tumbuh dan berkembang, mempersiapkan mahasiswa sedemikian rupa agar memiliki keunggulan bersaing (competitive adventage) pada saat proses seleksi dan pendidikan se- 
hingga menghasilkan lulusan yang bermutu. Keunggulan tersebut dipersiapkan berdasarkan harapan dan keinginan pelanggan. Perbaikan akan terus dilakukan berdasarkan infomasi dari pelanggan (Continous Quality Improvement) agar dapat terus menjadi pimpinan pasar dalam menghasilkan lulusan tenaga kesehatan yang bermutu di Propinsi Bengkulu.

Hal tersebut sesuai dengan pendapat Supranto (2001) bahwa mutu merupakan sesuatu yang harus dikerjakan dengan baik bagi penyedia jasa atau pelayanan. Aplikasi mutu sebagai suatu sifat dari penampilan produk atau kinerja merupakan bagian utama strategi perusahaan dalam rangka meraih keunggulan yang berkesinambungan, baik sebagai pemimpin pasar ataupun sebagai strategi untuk terus tumbuh. Keunggulan suatu produk jasa atau pelayanan adalah tergantung dari keunikan jasa tersebut, apakah sudah sesuai dengan harapan dan keinginan pelanggan.

Kepuasaan User (Institusi Pengguna) Terhadap Lulusan Poltekkes Kemenkes Bengkulu.

Hasil penelitian menunjukkan bahwa sebagian besar $(72,7 \%)$ pimpinan dan rekan kerja puas dengan kinerja lulusan Poltekkes Kemenkes Bengkulu. Hal ini sejalan dengan hasil penelitian tentang mutu lulusan Poltekkes Kemenkes Bengkulu di atas bahwa lebih dari separuh $(63,6 \%)$ user menyatakan mutu lulusan Poltekkes Kemenkes Bengkulu adalah baik, dan separuh $(51,1 \%)$ rekan kerja berpendapat mutu secara keseluruhan lulusan adalah baik. Mutu merupakan kepuasan pelanggan, sehingga apabila sebuah produk/pelayanan dikatakan bermutu maka produk/pelayanan tersebut akan memuaskan pelanggannya. Hal ini terjadi setelah pelanggan/pengguna lulusan dalam hal ini pimpinan dan rekan kerja membandingan kinerja dengan harapannya terhadap lulusan, dimana terdapat kesesuaian antara kinerja yang dirasakan dengan harapan mereka.
Hasil penelitian sejalan dengan pendapat Kotler (2002) bahwa kepuasan pelanggan/user adalah tingkat perasaan seseorang pemakai setelah membandingkan kinerja (atau hasil) yang dirasakan dengan harapannya. Jadi, tingkat kepuasan adalah fungsi dari perbedaan antara kinerja yang dirasakan dengan harapan. Kualitas termasuk semua elemen yang diperlukan untuk memuaskan tujuan pelanggan, baik internal maupun ekternal, juga termasuk tiap-tiap item dalam produk kualitas, kualitas layanan, performance, availibility, durability, aesthetic, reability, maintainability, logistic, supprtability, customer service, training, delivery, billing, shipping, repairing, marketing, warranty, dan life cycle cost.

Demikian juga menurut Tjiptono (2000), kepuasan dimulai dari kebutuhan dan keinginan pelanggan sesuai dengan harapan terhadap produk, sedangkan dari pihak produsen dimulai dari tujuan memberikan kepuasan terhadap pelanggan dengan membuat produk sesuai keinginan pelanggan. Begitu juga definisi singkat tentang kualitas yang dinyatakan oleh Juran (1993, dalam Gaspersz, 2003) bahwa kualitas adalah kepuasan pelanggan.

Menurut Zeithaml, Parasuraman \& Berry (1990 dalam Supranto, 2001) terdapat lima dimensi atau karakteristik mutu pelayanan yang dapat memberikan kepuasan kepada pelanggan, yaitu sebagai berikut: reliability (keandalan), responsiveness (ketanggapan), confidence (keyakinan), empathy (empati), dan tangible (berwujud).

Dengan demikian Poltekkes Kemenkes Bengkulu harus memperhatikan, memperbaiki dan meningkatkan dimensi mutu lulusan yang dihasilkannya agar dapat memberikan kepuasan kepada pelanggan/user.

\section{Posisi Lulusan Poltekkes Kemenkes Beng- kulu Pada Jendela Pelanggan (Customer Window)}

Berdasarkan hasil penelitian tentang korelasi data kualitatif untuk mengetahui seberapa dekat hubungan antara faktor-fak- 
tor/atribut dengan kepuasan pelanggan pengguna lulusan Poltekkes Kemenkes Bengkulu didapatkan bahwa nilai $\mathbf{X}=\mathbf{3 , 9 7}$ dan nilai $Y=\mathbf{4 , 4 2}$. Nilai tersebut merupakan titik potong pada diagram kartesius yang membagi jendela pelanggan menjadi empat kwadran.

Hasil penelitian menunjukkan bahwa terdapat 9 faktor (nomor : 1, 2, 11, 12, 18, 19, 25, 26, dan 30) yang berada di kwadran A, dimana faktor-faktor tersebut menunjukkan unsur-unsur keinginan/harapan yang sangat penting bagi user/rekan kerja tetapi lulusan Poltekkes Kemenkes Bengkulu belum melaksanakan sesuai keinginan/harapan tersebut, sehingga menimbulkan rasa tidak puas.

Hasil penelitian juga menunjukkan bahwa terdapat 14 faktor (nomor : 3, 7, 10, $13,14,16,20,23,24,27,34,35,36$, dan 40) yang berada di kwadran B, dimana faktor-faktor tersebut menunjukkan unsur-unsur keinginan/harapan yang sangat penting bagi user/rekan kerja dan telah dilaksanakan dengan baik oleh lulusan Poltekkes Kemenkes Bengkulu dan dapat memuaskan user/rekan kerja.

Berdasarkan penelitian juga diketa-hui bahwa terdapat 13 faktor (nomor : 4, 5,6, $8,17,21,28,29,31,32,37,38$, dan 39) yang berada di kwadran $\mathrm{C}$, dimana fak-torfaktor tersebut menunjukkan unsur-unsur keinginan/harapan yang kurang pen-ting bagi user/rekan kerja dan lulusan Poltekkes Kemenkes Bengkulu melaksanakan secara sedang/biasa saja.

Berdasarkan penelitian juga diketa-hui bahwa terdapat 4 faktor (nomor : 9, 15, 22, 33) yang berada di kwadran D, dimana faktor-faktor tersebut menunjukkan bahwa unsur-unsur keinginan/harapan yang kurang penting bagi user/rekan kerja tetapi dilaksanakan dengan sangat baik oleh lulusan Poltekkes Kemenkes Bengkulu sehingga terkesan berlebihan. Poltekkes Kemenkes Bengkulu harus menghentikan penawaran atau berusaha mendidik pelanggan/user tentang manfaat dari karakteristik yang ada pada lulusan.
Menurut Gaspersz (2003), empat kwadran diagram kartesius di atas yang dikenal dengan Jendela Pelanggan (Customer Window) dipakai untuk memahami ekspektasi pelanggan. Jendela pelanggan ini diperkenalkan oleh ARBOR, Inc., suatu perusahaan riset pasar dan Total Quality Management (TQM) yang berpusat di Philadelphia. Pendekatan jendela pelanggan dimulai dari klarifikasi dan segmentasi pelanggan, kemudian mendesain pertanyaanpertanyaan riset untuk mempelajari kepuasan relatif dan kepentingan relatif (urutan Prioritas) dari karakteristik produk/pelayanan yang diinginkan pelanggan. Hasil-hasil ini kemudian ditebarkan untuk memprioritaskan kesempatan perbaikan pada simple grid yang mewakii inti dari jendela pelanggan. Jendela pelanggan membagi karakteristik produk/pelayanan ke dalam empat kwadran, A, B, C, dan D.

Menggunakan jendela pelanggan sebagai alat analisis, kita dapat mengetahui apakah posisi produk kita berada dikotak A, B, C, atau D. Posisi terbaik apabila berada dalam kota $\mathrm{B}$ (Bravo), dimana dalam hal ini pelanggan memperoleh apa yang diinginkan dari mengkonsumsi produk/pelayanan yang ditawarkan sehingga pelanggan akan puas. Apabila posisi berada dalam kotak A (Attention), dalam hal ini membutuhkan perhatian kita karena pelanggan tidak memperoleh apa yang diinginkan sehingga pelanggan menjadi tidak puas. Jika posisi berada dalam kotak C (Cut or Communicate) atau kwadran D menurut Supranto (2001), kita harus menghentikan penawaran atau berusaha mendidik pelanggan tentang manfaat dari karakteristik produk/pelayanan yang ditawarkan, karena dalam posisi ini pelanggan memperoleh apa yang tidak diinginkannya. Sedangkan apabila berada dalam kota D (Don't Worry Be Happy) atau kwadran C menurut Supranto (2001), maka tidak menjadi masalah bagi kita karena pelanggan tidak memperoleh yang tidak diinginkannya (Gaspersz, 2003).

Berdasarkan hasil analisis di atas faktor-faktor/atribut yang terbanyak terdapat 
pada kwadran/Kotak B yaitu sebanyak 14 faktor, diikuti kwadran/ Kotak C (Supranto, 2001) sebanyak 13 faktor, kwadran/Kotak A sebanyak 9 faktor, dan kwadran/Kotak D (Supranto, 2001) sebanyak 4 faktor. Hal ini berarti bahwa faktor-faktor tersebut paling banyak berada kwadran yang membuat pelanggan memperoleh apa yang diinginkan dari mengkonsumsi produk/pelayanan yang ditawarkan sehingga pelanggan puas terhadap lulusan Poltekkes. Namun demikian sebanyak 9 faktor terdapat pada kwadran A yang artinya ada sembilan faktor/atribut yang ditampilkan lulusan tidak memenuhi harapan pelanggan/user yang membuat mereka tidak puas. Hal ini menjadi peringatan bagi Poltekkes Kemenkes Bengkulu untuk memperbaiki mutu lulusanya agar tidak ditinggalkan pelanggan/user.

\section{Masa Tunggu Lulusan Untuk Mendapatkan Pekerjaan}

Hasil penelitian diatas menunjukkan bahwa seluruh lulusan yang menjadi responden penelitian telah mendapat pekerjaan, dimana $37,7 \%$ lulusan telah berkerja sebagai pegawai negeri sipil, $23,4 \%$ lulusan dengan lama masa tunggu mendapat pekerjaan setelah lulus adalah $<3$ bulan dan $23,4 \%$ lulusan mendapat pekerjaan setelah menunggu 3-6 bulan. Hasil penelitian juga menunjukkan bahwa sebagian besar $(83,1 \%)$ lulusan Poltekkes Kemenkes Bengkulu bekerja sebagai PNS dan sebagian kecil $(6,5 \%)$ Honorer di Puskesmas dan sebagian kecil $(5,2 \%)$ bekerja sebagai Pegawai Tidak Tetap (PTT) di daerah terpencil.

Hal ini memperlihatkan bahwa lulusan Poltekkes Kemenkes Bengkulu sangat diminati dipasaran dan memiliki kemampuan yang lebih baik dalam bersaing dengan lulusan pendidikan tinggi kesehatan lainnya di Propinsi Bengkulu, di samping itu juga menunjukkan bahwa mutu lulusan Poltekkes juga lebih baik dan dapat memberikan kepuasan kepada user/pelanggan dalam bekerja. Masa tunggu yang lebih la- ma (> 12 bulan) menunjukkan bahwa mutu lulusan sebuah perguruan tinggi kurang baik, tidak dapat bersaing, dan tidak diminati oleh pelanggan/user, sehingga tidak terserap di pasar kerja.

Menurut Asmawi (2005), penyerapan lulusan perguruan tinggi ini sampai sekarang masih menjadi perdebatan karena adanya perbedaan di dalam melakukan pendekatan. Sedikitnya itu ada dua pendekatan yang berbeda; yakni pendekatan dari dunia kerja dan pendekatan kalangan perguruan tinggi. Pedekatan pertama, menyatakan bahwa lulusan perguruan tinggi tidak mampu bekerja sebagaimana yang diinginkan dunia kerja, yakni keahlian yang dimiliki masih jauh dari harapan. Pendekatan pertama ini menginginkan, lulusan perguruan tinggi itu harus memiliki keterampilan kerja (skill) yang memadai dan siap untuk bekerja. Kalangan perguruan tinggi sebenarnya tanggap dan merespon, sehingga disiapkan berbagai sarana dan prasarana, seperti komputerisasi, laboratorium, bengkel kerja dan pusat data. Namun pada Kenyataannya dalam membentuk keahlian itu tidaklah memadai dan tidak menyebar secara merata di setiap perguruan tinggi. Pendekatan ke dua, dari kalangan perguruan tinggi yang menyatakan bahwa sesuai dengan tujuan pendidikan yakni untuk berkembangnya potensi peserta didik agar menjadi manusia yang beriman dan bertakwa kepada Tuhan yang Maha Esa, berakhlak mulia, sehat, berilmu, cakap, kreatif, mandiri, dan menjadi warga negara yang demokratis serta bertanggung jawab (Pasal 4 UU RI Nomor 20 Tahun 2003).

Kecakapan dan keterampilan kerja (skill) itu memang tidak identik, keterampilan merupakan bagian dari kecakapan yang bisa dimiliki oleh calon lulusan. Pada pendekatan ke dua ini memang, tujuan pendidikan itu tidak disiapkan hanya untuk siap kerja, tetapi jauh lebih luas, yakni menyangkut pembentukan peserta didik menjadi manusia seutuhnya dan keterampi-lan merupakan hal yang penting yang da-pat dimiliki oleh seseorang. Namun demi-kian, seyogyanya perbedaan dua pendeka-tan 
yang berbeda ini harus dikembangkan adanya pemahaman yang mendalam sehingga tidak saling mengklaim benarnya sendiri, minimal dapat ditarik benang merahnya. Pedidikan sebagai suatu proses, pertama mengenal adanya raw-input dan instrumental input. Raw input merupakan peserta didik sedangkan instrumental input terdiri dari : gedung, perpustakaan, pedoman akademik, dosen, kurikulum, metode dan lain-lain. Kedua raw input dan instrumental input masuk dalam proses, yang ini akan memakan waktu beberapa semester. Ketiga, output (hasil didik) yang sesuai dengan kriteria institusi dan siap untuk masuk kedalam persaingan sumber daya manusia. Dosen merupakan instrumen yang sangat menentukan keberhasilan proses pendidikan, karena dari dosenlah perpindahan ilmu dilakukan kepada peserta didik.

Perguruan tinggi yang memiliki tenaga-tenaga dosen yang berkualitas akan banyak diminati oleh masyarakat. Karena itu program untuk meningkatkan kualitas para dosen adalah merupakan kewajiban yang tidak ditawar-tawar lagi pada saat ini dan dimasa mendatang. Perguruan tinggi yang tidak mau mengikuti arusnya perkembangan perubahan sekarang dan dimasa datang akan ditinggalkan oleh masyarakat dan lambat atau cepat akan mengalami kemunduran, yang akhirnya akan mengalami keruntuhan.

Faktor-Faktor yang diduga Berhubungan dengan Ketidakpuasan User Terhadap Lulusan Poltekkes Kemenkes Bengkulu

Berdasarkan hasil analisis dengan menggunakan jendela pelanggan diduga terdapat sembilan faktor berhubungan dengan ketidapuasan user terhadap lulusan Poltekkes Kemenkes Bengkulu. Adapun faktor-faktor tersebut adalah sebagai berikut :

1. Memberikan pelayanan dengan tepat sesuai dengan yang dijanjikan

2. Mengembangkan hubungan saling percaya dengan pelanggan, rekan kerja dan atasan
3. Menjaga peralatan kerja dalam keadaan bersih dan tertata rapi

4. Menjalankan jadwal pelayanan tepat waktu

5. Cepat tanggap menyelesaikan keluhan pelanggan/rekan kerja

6. Memberikan pelayanan dengan pengetahuan yang baik

7. Bersikap luwes dan supel

8. Mampu beradaptasi dan mengembangkan diri dengan cepat

9. Disiplin terhadap waktu dan pekerjaan.

Jika dilihat dari lima dimensi mutu pe-

layanan sebagai rujukan penyusunan instrumen penelitian, kesembilan faktor di atas dapat digolongan ke dalam dimensi tersebut, dengan rincian sebagai berikut: faktor no. 1, 2, 4, 8 dan 9, termasuk ke dalam dimensi reliability (keandalan); faktor No. 5, termasuk ke dalam dimensi responsiveness (ketanggapan), faktor no. 6, termasuk ke dalam dimensi confidence (keyakinan), faktor no. 3 dan 7 termasuk ke dalam dimensi tangible (berwujud).

Sehubungan dengan hal tersebut disarankan kepada peneliti selanjutnya untuk meneliti hubungan dimensi reliability, responsiveness, confidence, dan tangible dengan kepuasan user/institusi pengguna lulusan Poltekkes Kemenkes Bengkulu.

\section{KESIMPULAN}

Dari hasil dan pembahasan dalam penelitian ini maka dapat ditarik kesimpulan sebagai berikut :

1. Ilmu yang diperoleh lulusan di Poltekkes Kemenkes Bengkulu relevan dengan peningkatan karier, dan ada keterampilan lain yang diperoleh bermanfaat bagi kemajuan karier.

2. Keterampilan atau muatan tambahan yang membantu pengembangan karier adalah keterampilan mengoperasikan komputer.

3. Lulusan Poltekkes Kemenkes Bengkulu kurang menguasai bahasa Inggris.

4. Kompetensi keterampilan komunikasi lisan dan pemberdayaan masyarakat sangat dibutuhkan user/pelanggan dari 
lulusan Poltekkes Kemenkes Bengkulu.

5. User/pelanggan berpendapat mutu lulusan Poltekkes Kemenkes Bengkulu adalah baik.

6. Sebagian besar user puas dengan kinerja lulusan Poltekkes Kemenkes Bengkulu.

7. Faktor-faktor/atribut yang mempengaruhi kepuasan user/pelanggan terbanyak terdapat pada kwadran/Kotak B yaitu sebanyak 14 faktor.

8. Lama masa tunggu lulusan mendapat pekerjan setelah lulus adalah bervariasi antara $<3$ bulan dan 3-6 bulan.

9. Faktor-faktor yang diduga berhubungan dengan ketidakpuasan user/pelanggan adalah reliability, responsiveness, confidence, dan tangible dari dimensi mutu pelayanan .

Disarankan kepada pihak Poltekkes Kemenkes Bengkulu, sebagai berikut :

a. Lebih meningkatkan kompetensi atau kemampuan Bahasa Inggris mahasiswa melalui kebijakan penambahan jumlah SKS muatan lokal Bahasa Inggris dan kursus Bahasa Inggris di luar jam kuliah pada setiap jurusan, agar lulusan mampu berkomunikasi dalam bahasa tersebut dengan baik.

b. Hendaknya menambahkan kompetensi keterampilan komunikasi lisan dan pemberdayaan masyarakat yang sangat dibutuhkan user/pelanggan dari lulusan Poltekkes Kemenkes Bengkulu.

c. Hendaknya mempersiapkan mahasiswa sedemikian rupa agar memiliki keunggulan bersaing (competitive adventage) pada saat proses seleksi dan pendidikan sehingga menghasilkan lulusan yang bermutu. Keunggulan tersebut dipersiapkan berdasarkan harapan dan keinginan pelanggan. Perbaikan akan te-

\section{DAFTAR KEPUSTAKAAN}

Ardiana, Brahmayanti, dan Subaedi (2010). Kompetensi SDM UKM dan Pengaruhnya Terhadap Kinerja UKM di Surabaya. Jurnal Manajemen Dan Kewirausahaan, Vol.12, No. 1, Maret 2010: 42-55 rus dilakukan berdasarkan infomasi dari pelanggan (Continous Quality Improvement) agar dapat terus menjadi pimpinan pasar dalam menghasilkan lulusan tenaga kesehatan yang bermutu di Propinsi Bengkulu.

d. Lebih memperhatikan, memperbaiki dan meningkatkan dimensi mutu lulusan yang dihasilkannya agar dapat memberikan kepuasan kepada pelanggan/user. Mempertahankan dan terus meningkatkan kualitas pelayanan terhadap faktor-faktor/atribut yang berada di kwadran B agar dapat terus memberikan kepuasan kepada user, dan memperbaiki kualitas pelayanan terhadap faktor-faktor yang berada di kwadran A agar dapat menurunkan atau menghilangkan ketidakpuasan pelanggan.

e. Hendaknya hasil penelitian ini dapat ditindaklanjuti oleh Pudir I dan Ketua Jurusan terkait agar dapat menambah kompetensi/keterampilan yang belum ada atau meningkatkan kompetensi/keterampilan yang sudah ada tapi belum maksimal diperoleh oleh mahasiswa dalam proses perkuliahan.

f. Instrumen/Kuesioner penelitian ini hendaknya dapat dipergunakan secara berkesinambungan oleh Pudir III dan Subbag Adak untuk mendapatkan data secara terus menerus dari alumni dan user agar dapat memperbaiki kelemahan yang ada. Kuesioner untuk alumni dapat diberikan kepada alumni minimal setelah 1 tahun menamatkan pendidikan dan kuesioner untuk mengukur kepuasan pimpinan/user dan rekan kerja serta kompetensi alumni dapat diberikan kepada pimpinan/user dan rekan kerja minimal setelah 1 tahun alumni bekerja di tempat kerja tersebut.

Asmawi, M.R., (2005) Strategi Meningkatkan Lulusan Bermutu di Perguruan Tinggi. Makara, Sosial Humaniora, Vol. 9, No. 2, Desember 2005: 66-71.

Budiarto, E., (203). Metodologi Penelitan Kedokteran, Jakarta : EGC.

Djafar, (2011). Standar Kompetensi Tenaga Kesehatan Dalam Rangka Pengembangan Kuali- 
tas Diknakes. Jakarta : BPPSDM Kes Kemenkes RI

Gaspersz, V. (2008). Total Quality Management, Jakarta : PT Gramedia Pustaka Utama.

Hamidi, (2004). Metode Penelitian Kualitatif, Malang : Penerbitan UMM

Iman, N., (2006). Lulusan Jaman Sekarang. Diakses dari http://WordPress.com/ tanggal 3 September 2011

Khoiri, M. (2009). Upaya Peningkatan Mutu Lulusan Perguruan Tinggi Untuk Memenuhi Kebutuhan SDM Industri dengan Pendekatan TQME.

Kotler, P. (2002). Manajemen Pemasaran, Jakarta : Prehallindo.

Kurniawan, R., (2011). Pengembangan Kompetensi Sumber Daya Manusia Dan Bantuan Modal Usaha Pengaruhnya Terhadap Kinerja Usaha Mikro Kecil Menengah (UMKM) Monel Di Kabupaten Jepara, Skripsi-Fakultas Ekonomi Universitas Negeri Semarang.

Mitrani,A,Daziel, M. And Fitt, D. (1995). Competency Based Human Resource Management: Value-Driven Strategies for Recruitment, Development and Reward, Kogan Page Limited : London,
Pohan, I. S. (2003). Jaminan mutu pelayanan kesehatan : Dasar-dasar pengertian, Bekasi : Kesaint Blanc.

Riduwan. (2005). Metode \& teknik menyusun tesis, Bandung : Alfabeta

Robbins S (2006) Perilaku Organisasi, (Alih bahasa, Benyamin Molan) Edisi Ke-10, Klaten: PT. Indeks Gramedia.

Ryllatt, Alastair, et.al, (1995). Creating Training Miracles, AIM Australia

Sabarguna, B.S. (2005). Analisis pemasaran rumah sakit, Yogyakarta : KONSORSIUM Rumah Sakit Islam Jateng-DIY.

Setyowati, (2009). Pengembangan SDM Berbasis Kompetensi : Solusi Untuk Meningkatkan Kinerja Organisasi.

Spencer, M.Lyle and Spencer, M.Signe, (1993). Competence at Work : Models for Superrior Performance, John Wily \& Son,Inc, New York, USA,

Supranto. (2001). Pengukuran tingkat kepuasan pelanggan : Untuk menaikkan pangsa pasar, Jakarta : Rineka Cipta.

Wijono, D. (2000). Manajemen mutu pelayanan kesehatan : Teori, strategi, dan aplikasi, Vol. 1, Surabaya : Airlangga University Press. 